\title{
Influence of Monsoon on the Distribution of Organic Carbon in Inner Continental Shelf Core Sediments, South China Sea, Malaysia
}

(Pengaruh Monsun ke atas Taburan Karbon Organik dalam Sedimen Teras Pelantar Benua

Dalam di Laut China Selatan, Malaysia)

PANG SweE Yun, JURIFFAH ARIFFIn, HiI YII SIANG \& NORHAYATI MOHD TAHIR*

\begin{abstract}
Three short sediment cores (12-32 cm) from South China Sea off Southern Terengganu were collected during May (postNortheast monsoon) and September (pre-Northeast monsoon) 2007. The concentration of total organic carbon (TOC) obtained ranged from 0.41-2.23 and 0.38-2.31\% during post and pre-monsoon, respectively. ToC concentration was found to decrease with depth and distance from the coast and river mouth. In particular, station with close proximity to the coast exhibits most pronounced variation of TOC with depth. Besides spatial variation, it is noted that the seasonal variations also considerably affect the distribution and concentrations of TOC, where both near and offshore sampling stations showed significant variations in TOC content during May and September sampling. These findings suggest the importance of terrestrial organic carbon flux, physical mixing and seasonal variations in regulating the concentration and distribution of the organic carbon in the study area.
\end{abstract}

Keywords: Autochthonous organic carbon; fluvial transport; land-based organic matter; seasonal influence; Southern South China Sea

\section{ABSTRAK}

Tiga turus sedimen pendek (12-32 cm) telah diambil di Laut China Selatan dalam bulan Mei (pos-Monsun Timur Laut) dan September 2007 (pra-Monsun Timur Laut). Kepekatan jumlah karbon organik (TOC) yang diperoleh adalah antara 0.41-2.23\% bagi pos monsun manakala bagi pra-monsun adalah antara 0.38-2.31\%. Kepekatan ToC didapati berkurangan dengan jarak dari pesisir pantai dan muara sungai. Kepekatan TOC juga didapati berkurangan dengan kedalaman turus sedimen pada semua stesen, dengan stesen yang paling dekat dengan pesisir pantai mempamerkan perubahan kepekatan yang paling ketara. Perubahan musim juga memberi kesan kepada taburan dan kepekatan ToC dengan kedua-dua stesen berdekatan pesisir pantai dan luar pantai mempamerkan perbezaan kepekatan TOC yang signifikan pada musim Mei dan September. Penemuan ini menunjukkan bahawa fluks karbon organik daratan, percampuran fizikal dan perubahan musim adalah penting dalam mengawal kepekatan dan taburan karbon organik di kawasan kajian.

Kata kunci: Angkutan sungai; bahan organik daratan; karbon organik autokran; Laut China Selatan; pengaruh musim

\section{INTRODUCTION}

Marine sediments receive two types of organic carbon (OC), particular the terrestrial OC, which is mainly transported through river discharge and to a lesser extent through atmospheric deposition; and in-situ production of OC by marine organisms (i.e. autochthonous OC) (Burdige 2007; Yunker et al. 2005). Often, terrestrial organic matter (OM) is made up of living biomass, plant litter and soil organic matter while autochthonous marine OM is greatly enriched with proteins, carbohydrates and lipids which is derived from phytoplankton detritus (Burdige 2007). An estimated $75-95 \%$ of the land-derived sediment was brought to the oceans worldwide by the rivers (Syvitski et al. 2003) and about $1 \%$ of the total organic carbon carried by rivers is derived from the terrestrial productivity (Hedges \& Keil 1995). Of all the terrestrial and marine originated OM, it is found that only less than $10 \%$ of these om reach the ocean floor and less than $0.5 \%$ is preserved in the marine sediments
(Hedges \& Keil 1995). In terms of its spatial distribution, organic carbon in marine sediment tends to decrease both with distance offshore and distance from major rivers (Hedges \& Keil 1995; Yunker et al. 2005) due to particle settling and dilution effect by mineral matters (Prahl et al. 1994). Therefore, it is generally known that the continental margins play an important role in regulating the global oc cycle as over $80 \%$ of the global OC is found in these shallow marine environment (Hedges \& Keil 1995). In view of its great importance, studies on source, distribution and composition of sedimentary OM are often crucial for the understanding the mechanisms and roles of OM in the global organic carbon cycle (Hu et al. 2009).

In Malaysia, the distribution of OM in riverine, estuarine and mangrove sediments is well established (Bakhtiari et al. 2010; Kamaruzzaman et al. 2010; Mohd Tahir et al. 2009). However, there is still very limited information on the distribution of OM in the marine environment off Southern 
Terengganu coast (Hasrizal et al. 2009; Mohd Ali et al. 2011). In view of this, the present study has been undertaken to determine the distribution of organic carbon in the inner continental shelf core sediments (within $50 \mathrm{~km}$ from the coast) off Southern Terengganu coast. In addition, this study also aimed to examine the influence of terrestrial input and monsoon seasons on the organic carbon distribution in the Southern South China Sea.

\section{MATERIALS AND METHODS}

\section{STUDY AREA}

The sampling area lies on the Sunda shelf with shallow waters $(<50 \mathrm{~m})$. It is located in the monsoon belt, thus, experiencing a unique climatic feature created by the Northeast monsoon (from November or early December through March) and Southwest monsoon (from the later half of May or early June and ends in September or early October) (Morton \& Blackmore 2001). These two monsoons are separated by two relatively shorter inter monsoon periods (April-May and October through to early November). Several rivers discharge its waters into the study area where main rivers include Sungai Dungun $\left(1399 \mathrm{~km}^{2}\right)$, Sungai Paka $\left(746 \mathrm{~km}^{2}\right)$ and Sungai Kemaman $\left(1399 \mathrm{~km}^{2}\right)$; smaller rivers include Sungai Kerteh, Sungai Chukai and Sungai Kemasik with total drainage area of approximately $653 \mathrm{~km}^{2}$ (DOE 1986). A ${ }^{210} \mathrm{~Pb}$ profile for cores taken in the South China Sea off the coast of Kuala Terengganu and Kuantan (approximately $100 \mathrm{~km}$ to the north and $40 \mathrm{~km}$ to the south of the present study area) showed sedimentation rate ranging between 1.2 and 1.4 $\mathrm{mm} \mathrm{yr}^{-1}$ with surface mixed layer limited to the upper 10 $\mathrm{cm}$ of the core (Wan Mahmood et al. 2010). For this study, three short sediment cores $(12-32 \mathrm{~cm})$ were collected during May 22-26, 2007 (post Northeast monsoon) and September 4-9, 2007 (pre-Northeast monsoon) cruises, respectively, using a gravity corer. The sampling stations were located in the inner continental shelf off Dungun and Kemaman coast, covering an area of approximately $2464 \mathrm{~km}^{2}$ (56 km in width $\times 45 \mathrm{~km}$ in length) (Figure 1). Samples were collected at the same locations during May and September; station coordinates, distance from the coastline and core length collected at each sampling station are outlined Table 1.

\section{SAMPLE ANALYSIS}

Once collected, core samples were kept refrigerated $\left(-4^{\circ} \mathrm{C}\right)$ during transport to the laboratory. In the laboratory, the cores were stored at $-4^{\circ} \mathrm{C}$ until further analysis. Once thawed, each core was sectioned into $2 \mathrm{~cm}$ intervals and every section was then packed in an aluminium foil bag prior to freeze-drying. Freeze-dried sediments were then

TABLE 1. Coordinates and core lengths of sampling stations

\begin{tabular}{cccccc}
\hline \multirow{2}{*}{ Station } & \multicolumn{2}{c}{ Coordinates } & $\begin{array}{c}\text { Approximate distance } \\
\text { from coastline/km }\end{array}$ & \multicolumn{2}{c}{ Core lengths (cm) } \\
& Latitude & Longitude & & $\begin{array}{c}\text { Post Northeast } \\
\text { Monsoon } 2007\end{array}$ & $\begin{array}{c}\text { Pre-Northeast } \\
\text { monsoon } 2007\end{array}$ \\
\hline ST1 & $4^{\circ} 45.000^{\prime} \mathrm{N}$ & $103^{\circ} 28.500^{\prime} \mathrm{E}$ & 6 & 32 & 32 \\
ST2 & $4^{\circ} 45.000^{\prime} \mathrm{N}$ & $103^{\circ} 42.021^{\prime} \mathrm{E}$ & 30 & 32 & 12 \\
ST3 & $4^{\circ} 15.000^{\prime} \mathrm{N}$ & $103^{\circ} 52.620^{\prime} \mathrm{E}$ & 45 & 16 & 32 \\
\hline
\end{tabular}

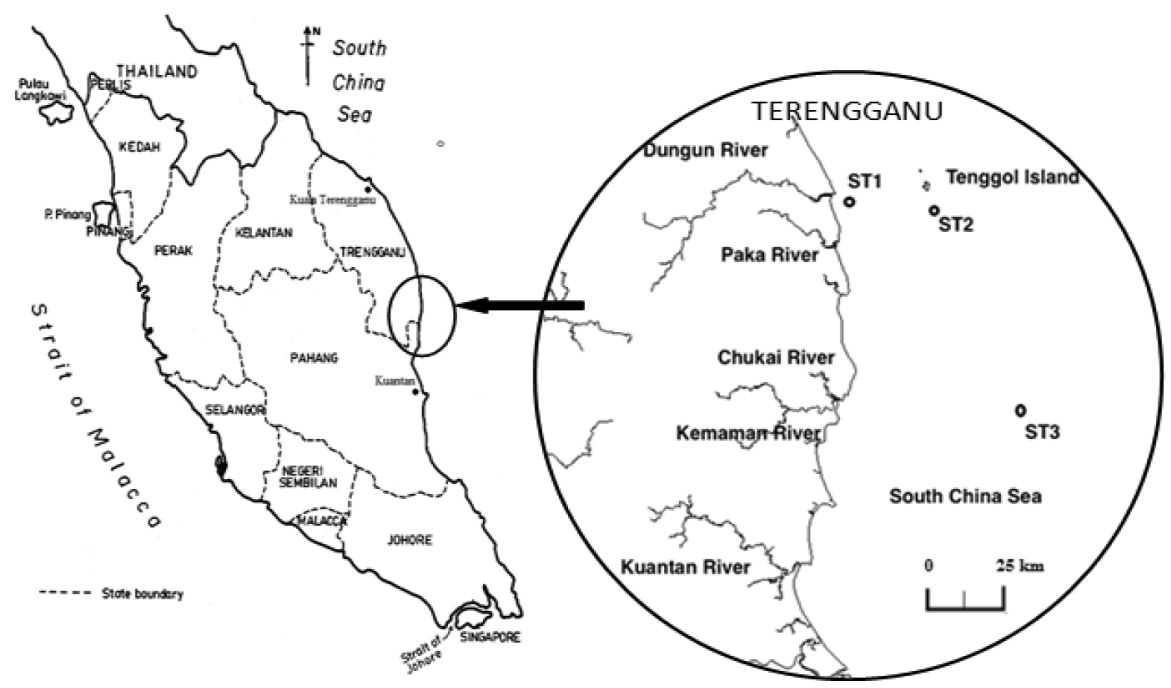

FIGURE 1. Location map of sampling sites 
homogenized and sieved through $600 \mu \mathrm{m}$ mesh. Only the sediment with fraction less than $600 \mu \mathrm{m}$ was used for the total organic carbon (TOC) analysis. The TOC in sediment was determined using the Walkley-Black's rapid titration method (Moris \& Singh 1971). The OC was oxidized with acidic dichromate solution followed by back titration of the excess dichromate solution with ferrous ammonium sulphate using diphenylamine as indicator. This method has a detection limit of approximately $0.10 \%$ and on homogeneous sample material, is generally reproducible within $8 \%$ (Nelson \& Sommers 1982). Statistical analyses were conducted using Statplus and Microsoft Excel. The data were subjected to a two-way ANOVA to determine differences of TOC content among locations and depths. Significance of difference between means was then tested by post hoc Scheffe's test.

\section{RESULTS AND DISCUSSION}

Figure 2 shows the vertical profile of TOC in sediment cores for the two sampling occasions. In general, the TOC obtained for the three cores ranged from $0.41-2.23 \%$ and $0.38-2.31 \%$ during the post Northeast monsoon and preNortheast monsoon sampling period, respectively (Table 2 ). For both sampling periods, highest TOC was found in core ST 1 followed by core ST2 and ST3. In station ST1, the highest TOC was observed at the surface $(0-2 \mathrm{~cm})$ for post Northeast monsoon sampling and at sub-surface (2-4 $\mathrm{cm})$ for pre-Northeast monsoon sampling. For ST2 and ST3, the highest TOC was recorded at depth 2-4 cm for post Northeast monsoon sampling and at $6-8 \mathrm{~cm}$ for preNortheast monsoon sampling. The TOC content observed at these two offshore stations were generally lower than the ST1 core. The TOC content at ST1 was significantly different from ST2 and ST3 $(p<0.05)$ but no significant difference in the TOC content was found between ST2 and ST3 $(p>0.05)$ for post monsoon sampling period. For preNortheast monsoon sampling period, all three stations showed significantly difference $(p<0.05)$ in TOC content from each other. Vertical profile of TOC at station ST1 shows an obvious variation in TOC $(p<0.05)$ for both post and pre-Northeast monsoon sampling periods. In contrast, little variation of TOC content was observed in ST2 and ST3 cores despite the significant variation of TOC $(p<0.05)$ with depth (Table 2). Interestingly, ST1 and ST2 cores exhibited higher TOC values during pre-Northeast monsoon relative to post monsoon sampling whereas ST3 behaved differently with lower values observed during pre-monsoon sampling.

The trend of decreasing TOC content with distance from the coast and rivers observed in this study is

TABLE 2. Comparison of TOC contents in sediment under different environment

\begin{tabular}{|c|c|c|}
\hline Areas & TOC Values & References \\
\hline $\begin{array}{l}\text { Southern Terengganu waters, Malaysia }(5-50 \mathrm{~km} \\
\text { off Dungun-Kemaman coast), Southern South } \\
\text { China Sea }\end{array}$ & $\begin{array}{l}\text { Post Northeast sampling } \\
0.77-2.23 \% \text { (surface, } 0-2 \mathrm{~cm} \text { ) } \\
0.59-2.23 \% \text { (ST1 core) } \\
0.41-0.96 \% \text { (ST2 core) } \\
0.47-0.83 \% \text { (ST3 core) } \\
\text { Pre-Northeast sampling } \\
0.50-1.95 \% \text { (surface, } 0-2 \mathrm{~cm} \text { ) } \\
1.01-2.31 \% \text { (ST1 core) } \\
0.61-0.84 \% \text { (ST2 core) } \\
0.38-0.51 \% \text { (ST3 core) }\end{array}$ & Present study \\
\hline $\begin{array}{l}\text { Terengganu coastal waters (from Besut to Marang), } \\
\text { Malaysia, Southern South China Sea. North of } \\
\text { present study site }\end{array}$ & $\begin{array}{l}\text { surface } \\
\quad \text { Pre-monsoon: } 0.80-1.80 \% \\
\text { Post monsoon: } 0.24-1.32 \%\end{array}$ & Hasrizal et al. (2009) \\
\hline Setiu Wetland (estuary-lagoon environment) & $\begin{array}{l}\text { surface } \\
1.43-1.99\end{array}$ & Mohd Tahir et al. (2009) \\
\hline Pahang river, Malaysia (estuary) & $\begin{array}{l}\text { surface } \\
\text { Pre-monsoon: } 1.61 \pm 0.55 \% \\
\text { Post monsoon: } 0.88 \pm 0.63 \%\end{array}$ & Kamaruzzaman et al. (2010) \\
\hline $\begin{array}{l}\text { Pulau Tinggi, island in southern South China Sea } \\
\text { off Johor (estuarine - coastal environment) }\end{array}$ & $\begin{array}{l}\text { surface } \\
2.00-13.0 \%\end{array}$ & Mohd Ali et al. (2011) \\
\hline Klang River, Malaysia (estuary) & $\begin{array}{l}\text { surface } \\
\quad 1.24-2.82 \%\end{array}$ & Bakhtiari et al. (2010) \\
\hline Nanshua Sea, South China Sea (continental slope) & $\begin{array}{l}\text { Core } 103(19-174 \mathrm{~cm} \text { depth }) \\
0.64-0.74 \\
\text { Core } 102(35-351 \mathrm{~cm} \text { depth }) \\
0.34-0.74 \%\end{array}$ & Duan (2000) \\
\hline Bohai Strait, North China (Gulf, coastal) & $\begin{array}{l}\text { surface } \\
0.04-0.69 \%\end{array}$ & Hu et al. (2009) \\
\hline
\end{tabular}


(a)

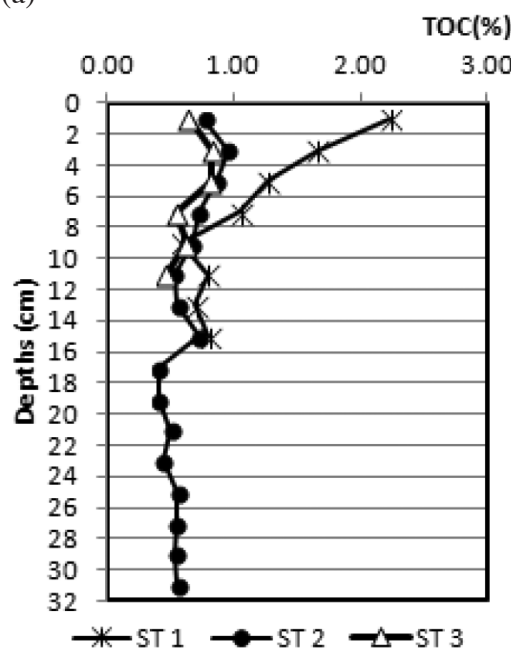

(b)

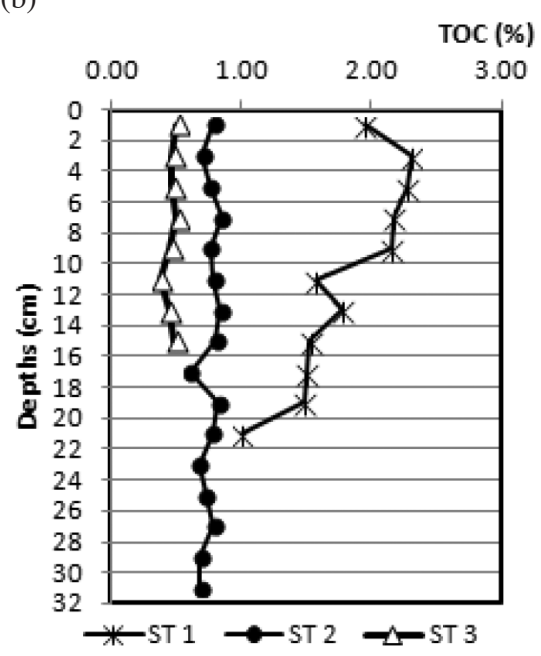

FIGURE 2. Vertical profile of total organic carbon (TOC) in core sediments for: (a) post Northeast monsoon and; (b) pre-Northeast monsoon sampling periods in year 2007

consistent with earlier reports (Hedges \& Keil 1995; Prahl et al. 1994; Yunker et al. 2005). Pronounced difference in TOC levels at the upper layer of ST1 compared with ST2 and ST3, especially during the post monsoon, suggest a stronger influence of riverine input to ST1; whereas lower TOC concentration observed in offshore stations is not surprising as these stations were located further away from the coast. Therefore, it is expected that the influence of fluvial transport would be relatively less significant at these stations (ST2 and ST3). In-situ production of OM becomes increasingly important with distance from the coastline as shown by the narrow range of OM with depth for ST2 and ST3. Such slight difference in TOC pattern between both stations could be explained by the presence of Pulau Tenggol in the sampling vicinity, which might have contributed additional source of terrestrial OC to ST2 despite the predominant marine based (autochthonous) OC. A substantial decrease in TOC with core depth, particularly in ST1 core, reflects the decomposition of OM. Similar observation was also reported by Duan (2000) and Venkatesan (1988). Episodic input of more concentrated biogenic material to the study area, bioturbation, physical mixing in the core sediments or some combination of these processes, could not be ruled out as demonstrated by variations in the TOC depth profile particularly for ST1 core during pre-Northeast monsoon sampling which exhibited a sub-surface maxima. In this case, the TOC values initially increased and maximized at $4 \mathrm{~cm}$ depth before it gradually decreased down the core.

Comparison between seasons showed that the TOC content at the surface sediments $(0-2 \mathrm{~cm})$ ranged from $0.64-2.23 \%$ during post Northeast monsoon and 0.50 $1.95 \%$ during pre-Northeast monsoon, indicating that the TOC content in the surface marine sediments during post monsoon was slightly higher than the pre-monsoon. Such enrichment of $\mathrm{OC}$ in the post-monsoon samples could be explained by the higher river discharge/run off that flushes appreciable amount of oM into the open sea during the Northeast monsoon, whereas reason for the lower organic carbon in sediments during the pre-Northeast monsoon may be caused by the dispersion of oM during the intensified Southwest monsoon. Hasrizal et al. (2009) also reported that the OC content in sediments varied with monsoon changes; however, their results showed higher TOC values during pre-Northeast monsoon. Besides mentioning the input of OM from river, the authors also suggested possible OM contribution from autochthonous production. In general, the surface TOC values $(0-2 \mathrm{~cm})$ found in the present study were comparable to other studies done in Malaysia and areas within the South China Sea as reported in Table 2 .

\section{CONCLUSION}

The results obtained from this study suggested the importance of fluvial transport of terrestrial OM into near coastal areas. In addition, significant variation of TOC concentration with depth and the seasonal and spatial variation of TOC vertical profile suggest processes such as monsoon seasons, physical mixing, biodegradation and/or episodic input of high concentration of OM might played an important role in regulating the concentration and distribution of the organic carbon in the study area.

\section{ACKNOWLEDGEMENTS}

The authors wish to thank The Ministry of Science, Technology and Innovation (MOSTI) for the financial support of this project (04-01-12-SF0065). The technical staff of INOS, UMT is acknowledged for their support during sample collection. Thanks to Dr. Peter Parhamp (INOS) for his valuable comments and assistance in proof reading this manuscript. This paper is dedicated to the late Prof Law Ah Theem who supported the initiation of this project. 


\section{REFERENCES}

Bakhtiari, A.R., Zakaria, M.P., Yaziz, M.I., Hj Lajis, M.N., Bi, X., Mohd Shafiee, M.R. \& Sakari, M. 2010. Distribution of PAHs and n-alkanes in Klang River surface sediment, Malaysia. Pertanika Journal of Science \& Technology 18: 167-179.

Burdige, D.J. 2007. Preservation of organic matter in marine sediment: Controls, mechanisms, and imbalance in sediment organic carbon budgets? Chemical Reviews 107: 407-485.

Department of Environment (DOE). 1986. Water Quality Criteria and Standards for Malaysia. Volume 2: General Guidelines and Review on Water Resources. Final report prepared by Universiti Malaya Consultancy Team for the Department of Environment, Malaysia.

Duan, Y. 2000. Organic geochemistry of recent marine sediments from the Nansha Sea, China. Organic Geochemistry 31: 159-167.

Hasrizal, S., Kamaruzzaman, B.Y., Sakri, I., Ong, M.C. \& Azhar, M.S.N. 2009. Seasonal distribution of organic carbon in the surface sediments of the Terengganu nearshore coastal area. American Journal of Environmental Sciences 5(1): 111-115.

Hedges, J.I. \& Keil, R.G. 1995. Sedimentary organic matter preservation: An assessment and speculative synthesis. Marine Chemistry 49: 81-115.

Hu, L., Guo, Z., Feng, J., Yang, Z. \& Fang, M. 2009. Distributions and sources of bulk organic matter and aliphatic hydrocarbons in surface sediments of the Bohai Sea, China. Marine Chemistry 113: 197-211.

Kamaruzzaman, Y., Siti Waznah, A., Shahbudin, S., Jalal, K.C.A. \& Ong, M.C. 2010. The temporal variation of organic carbon during the pre-monsoon and post monsoon in Pahang River Estuary, Pahang, Malaysia. Oriental Journal of Chemistry 26(4): 1309-1313.

Mohd Ali, M., Humrawali, N., Latif, M.T. \& Zakaria, M.P. 2011. Composition and sources of sterols in Pulau Tinggi, Johor, Malaysia. Sains Malaysiana 40(2): 111-118.

Mohd Tahir, N., Abd. Rahim, H.M., Tay, J.H., Fadzil, M.F. \& Abas, M.R. 2009. Distribution and sources of hydrocarbons in lagoon sediments of Setiu Wetland, Terengganu, Malaysia. Aquatic Ecosystem Health and Management 12(4): 344-349.

Moris, N. \& Singh, M.M. 1971. Manual of Laboratory Method of Chemical Soil Analysis. Kuala Lumpur: Rubber Research Institute of Malaysia. pp.13-15.

Morton, B. \& Blackmore, G. 2001. South China Sea. Marine Pollution Bulletin 42(12): 1236-1263.

Nelson, D.W. \& Sommers, L.E. 1982. Total carbon, organic carbon and organic matter. In Methods of Soil Analysis: Part 2. Chemical and Microbiological Properties, edited by Page, A.L., Miller, R.H. \& Keeney, D.R. ASA Monograph Number 9. pp. 539-579.
Prahl,F.G.,Ertel, J.R., Goñi, M.A., Sparrow, M.A. \& Eversmeyer, B. 1994. Terresterial organic carbon contributions to sediments on the Washington margin. Geochimica et Cosmochimica Acta 58: 3035-3048.

Syvitski, J.P.M., Peckham, S.D., Hilberman, R. \& Mulder, T. 2003. Predicting the terrestrial flux of sediment to the global ocean: A planetary perspective. Sedimentary Geology 162: 5-24.

Venkatesan, M.I. 1988. Organic geochemistry of marine sediments in Antarctic region: Marine lipids in McMurdo Sound. Organic Geochemistry 12(1): 13-27.

Wan Mahmood, Z.U., Mohamed, C.A.R., Yii, M.W., Ahmad, Z., Ishak, K. \& Ishak, A.K. 2010. Vertical inventories and fluxes of 210Pb, 228Ra and 226Ra at southern South China Sea and Malacca Straits. Journal of Radioanalytical Nuclear Chemistry 286: 107-113.

Yunker, M.B., Belicka, L.L., Harvey, H.R. \& Macdonald, R.W. 2005. Tracing the inputs and fate of marine and terrigenous organic matter in Arctic Ocean sediments: A multivariate analysis of lipid biomarkers. Deep-Sea Research II 52 : 3478-3508

Pang Swee Yun, Juriffah Ariffin \& Norhayati Mohd Tahir* Environmental Research Group

School of Marine and Environmental Science Universiti Malaysia Terengganu, Mengabang Telipot 21030 Kuala Terengganu, Terengganu Darul Iman Malaysia

Hii Yii Siang \& Norhayati Mohd Tahir*

Fellow Institute of Oceanography and Environment Universiti Malaysia Terengganu, Mengabang Telipot 21030 Kuala Terengganu, Terengganu Darul Iman Malaysia

Hii Yii Siang

School of Aquaculture and Fisheries Science Universiti Malaysia Terengganu, Mengabang Telipot 21030 Kuala Terengganu, Terengganu Darul Iman Malaysia

*Corresponding author; email: hayati@umt.edu.my

Received: 4 August 2014

Accepted: 17 February 2015 